Proc. Estonian Acad. Sci. Geol., 2004, 53, 3, 149-164

\title{
Outlines of the Precambrian basement of Estonia
}

\author{
Alvar Soesoo $^{\mathrm{a}}$, Väino Puura ${ }^{\mathrm{b}}$, Juho Kirs ${ }^{\mathrm{b}}$, Valter Petersell ${ }^{\mathrm{c}}$, \\ Mati Niin ${ }^{c}$, and Tarmo All ${ }^{\mathrm{b}, \mathrm{c}}$ \\ ${ }^{\text {a }}$ Institute of Geology at Tallinn University of Technology, Estonia pst. 7, 10143 Tallinn, Estonia; \\ Alvar.Soesoo@gi.ee \\ ${ }^{\mathrm{b}}$ Institute of Geology, University of Tartu, Vanemuise 46, 51014 Tartu, Estonia \\ ${ }^{c}$ Geological Survey of Estonia, Kadaka tee 82, 12816 Tallinn, Estonia
}

Received 25 February 2004

\begin{abstract}
The crystalline basement of Estonia can be subdivided into two major geological units North Estonian amphibolite and South Estonian granulite complexes. The amphibolite facies terrain consists of a sequence of metavolcanics and -sediments, which resemble those of the island arc sequences in southern Finland. The South Estonian granulites, probably belonging to the BelarusBaltic Granulitic Belt, show the peak metamorphism conditions of about $800^{\circ} \mathrm{C}$ and $5-6 \mathrm{kbar}$. U-Pb isotopic data demonstrate that the Estonian basement has formed during the Palaeoproterozoic, 1.9-1.8 Ga ago and is composed of magmatic, volcanic, and sedimentary components across major structural zones. The granulite metamorphism postdates these ages $(1.79-1.73 \mathrm{Ga})$. The youngest igneous rocks in the basement belong to the Fennoscandian Palaeo-Mesoproterozoic Rapakivi Province and include the composite Riga batholith, as well as at least five minor stock-like porphyritic K-granite plutons (ca. $1.6 \mathrm{Ga}$ ).
\end{abstract}

Key words: petrology, geochronology, magmatism, Palaeoproterozoic, Estonian basement.

\section{INTRODUCTION}

The crystalline basement of Estonia, which is covered by 100-780 m thick Palaeozoic sedimentary rocks, consists of Palaeoproterozoic metamorphic and igneous rocks. Since there are no outcrops of the crystalline basement rocks, drill core material and geophysical and geochemical methods were used for geological study of these rocks. More than half a century research of the basement rocks has led to publication of a large number of reports (mostly in Russian) and papers and one monograph (Puura et al. 1983), in addition to several regional geological maps (Grigelis \& Puura 1978; Puura 1980; Koistinen 1994). Recently, 
the geological map of the crystalline basement of Estonia at a scale of 1:400 000 was compiled (Koppelmaa 2002). The structure of the crystalline basement displayed on the map is based on the results of complex (petrographical, petrophysical, and geochemical) investigations of $32500 \mathrm{~m}$ of drill cores of crystalline rocks from 490 drill holes, as well as on the information obtained by gravimetric and magnetometric survey.

The uppermost section of the Estonian basement includes an ancient, predominantly kaolinitic (together with montmorillonite and illite) weathering crust, with a thickness from a few to several tens of metres (up to $150 \mathrm{~m}$ in NE Estonia). Due to intense denudation during the late Proterozoic, the surface of the basement has turned into a peneplain, which dips gently (on average $0.10-0.20^{\circ}$, i.e. 2-3.5 $\mathrm{m}$ per $\mathrm{km}$ ) southward (SSE-SSW $150-200^{\circ}$ ). The crystalline basement lies at a depth of $67.5 \mathrm{~m}$ on Vaindloo Island (Gulf of Finland), at $103.5 \mathrm{~m}$ on the Juminda Peninsula, at $629.0 \mathrm{~m}$ in Häädemeeste (SW Estonia), and at $784.1 \mathrm{~m}$ on Ruhnu Island (Gulf of Riga). The relatively plain surface of the crystalline basement is disturbed by some erosional relief forms, tectonic escarpments, and dome-shaped uplifts, such as the Sonda-Uljaste and Assamalla uplifts in NE Estonia, the Mõniste Uplift in SE Estonia, also the rim wall of the Kärdla impact crater on Hiiumaa Island (West Estonian Archipelago).

On the basis of geophysical and petrological studies, the Estonian basement can be divided into two major geological units - North Estonian amphibolite facies and South Estonian granulite facies complexes, which are separated from each other by a tectonical boundary (Paldiski-Pskov shear zone) and include six petrological-structural zones: the Tallinn, Alutaguse, Jõhvi, West Estonian, Tapa, and South Estonian zones (Fig. 1). These zones differ in rock associations (metasediments or metavolcanites/igneous intrusions), degree of metamorphism and petrophysical properties of rocks reflected in their gravity and magnetic fields. The aim of this paper is to present a brief overview of the Estonian Precambrian basement, petrography and geochemistry of its rock types, geophysical fields and metamorphism.

\section{THE POSITION OF THE ESTONIAN BASEMENT WITHIN THE SVECOFENNIAN DOMAIN AND THE CHARACTERISTICS OF PETROLOGICAL-STRUCTURAL ZONES}

A. Öpik was the first to imply in 1942 (Öpik 1942) that the Estonian basement belongs to the Svecofennian orogenic system in the Fennoscandian Shield. Later, geologists declined from that idea and suggested that higher-grade metamorphic rocks of South Estonia, Latvia, Lithuania, and NW Belarus (the Baltic-Belarus High), usually complemented by high geophysical anomalies, can be correlated with other high-grade metamorphic complexes in East and NE Europe and thus can be considered to be of Archaean age (Puura et al. 1976; Gorbatschev \& Gaal 1987). 


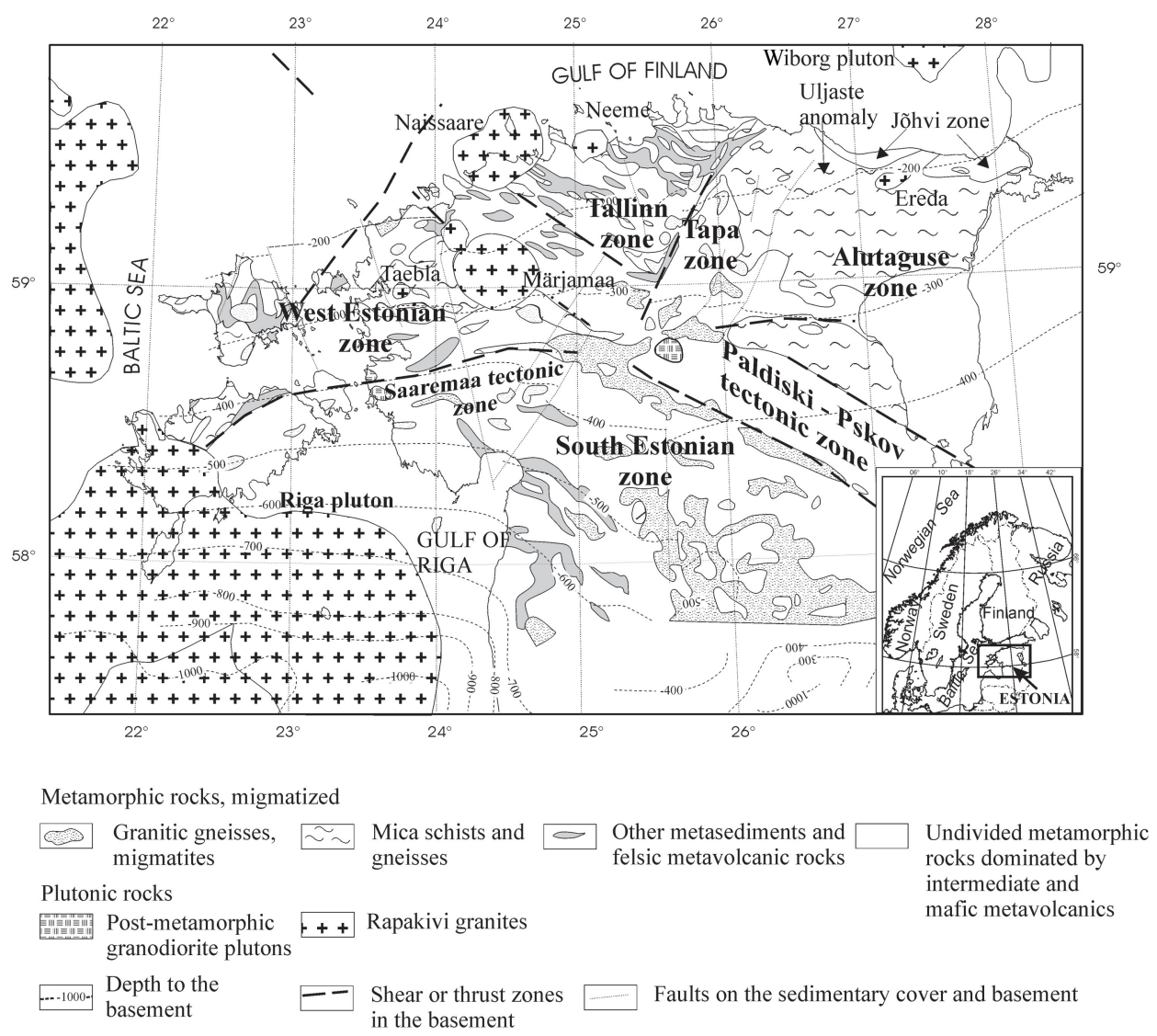

Fig. 1. The structural and metamorphic zonation of the Precambrian basement of Estonia. Major rock units and tectonic boundaries are shown.

The studies of the Estonian crystalline rocks (e.g. Puura et al. 1983 and references therein) have corroborated that at least the basement of North Estonia is a part of the large Archaean-Proterozoic Fennoscandian/Baltic Shield (continuation of the Svecofennian orogenic zone). However, there is no direct evidence of the extent of the shield rocks towards the south. Until the late 1980s, the granulitic rocks of the South Estonian complex were considered as Archaean, or at least pre-Svecofennian in age (Puura et al. 1983; Gorbatschev \& Gaal 1987). This assumption was based on lithological correlations of granulite facies rocks with those of the Kola series (Bondarenko \& Dagelaiskii 1968) and on the idea that regional granulite facies rocks should be older than their lower-grade surroundings.

However, the results of the Sm-Nd and U-Pb isotopic studies (Huhma et al. 1991; Petersell \& Levchenkov 1994) suggest that the South Estonian granulites are more likely early Proterozoic than Archaean in age. The studied granulites 
yielded mantle extraction model ages of about $2 \mathrm{Ga}$, being thus younger than Archaean but somewhat older than typical Svecofennian rocks in southern Finland and Sweden. New isotopic studies confirmed the Proterozoic ages of Estonian granulites (depleted mantle ages vary between 2.0 and $2.28 \mathrm{Ga}$; A. Soesoo and R. Kuldkepp, unpublished data).

Based on petrographic and geochemical similarities, the North Estonian amphibolite facies rocks were believed to belong to a section of Svecofennian rocks cropping out in southern Finland. This view has remained unchanged. More studies are needed to establish the structural-geological position of the South Estonian granulites.

Ideas about the magmatic and tectonic evolution of the Svecofennian orogen have changed during the last decades. Hietanen (1975) proposed a model, which explains rock variations in the Fennoscandian Shield by the opening of an oceanic basin, subduction, and island arc magmatism. More recent and complex magmatic and tectonic models have been proposed by Baker et al. (1988), Gaal (1990), Park (1991), Lahtinen (1994), and Nironen (1997). In recent models, the evolution of the Svecofennian Domain is interpreted as multiple, time- and space-dependent subduction-related collisions of several island-arc structures. It is thought that the 1.91-1.8 Ga magmatism and metamorphism were related to these collisions. According to Nironen (1997), the basement rocks of Estonia were also involved in these magmatic, tectonic, and metamorphic events.

\section{GEOLOGICAL FEATURES OF PETROLOGICAL-STRUCTURAL ZONES OF ESTONIAN PRECAMBRIAN BASEMENT}

The crystalline basement of Estonia comprises Palaeoproterozoic metamorphic and igneous rocks, and the Subjotnian (late Palaeoproterozoic to early Mesoproterozoic) population of rapakivi granite-anorthosite suites. Based upon geophysical and petrological studies, six petrological-structural zones of the metamorphic basement are distinguished, each of those displaying characteristic features: the Tallinn, Alutaguse, Jõhvi, West Estonian, Tapa, and South Estonian zones (Puura et al. 1983). These zones mostly differ in rock assemblages (of metasedimentary or metavolcanic/-igneous origin), metamorphic grade and petrophysical properties of rocks reflected in their gravity and magnetic fields.

The Tallinn zone is characterized by low gravity and magnetic fields, which form weak linear NW-SE trending anomalies. The zone is bordered by a regional Åland-Paldiski-Pskov shear zone in the southeast, which separates it from the West Estonian zone. Another extensive tectonic disturbance zone separates the Tallinn zone from the Tapa zone in the east. The rocks of the Tallinn zone vary from mafic amphibolite facies metavolcanites to metasediments represented by amphibole gneisses, biotite-plagioclase gneisses, quartz-feldspar gneisses, mica gneisses, and minor sulphide-graphite gneisses and magnetite quartzites (Jägala complex). Migmatization is generally common and strong in places. 
East of the Tallinn zone, the Alutaguse zone and the smaller Jõhvi zone are distinguished. The Alutaguse zone is characterized by low gravity and magnetic fields. Several positive anomalies are known in the area of Sonda-Uljaste and Assamalla dome-like structures and in the Haljala area, which are associated with sulphide-graphite gneisses (black schists), quartzites, skarned carbonaceous rocks, and pyroxene gneisses. The main rock types of the zone are Al-rich gneisses (with biotite, cordierite, garnet, and sillimanite) and biotite-plagioclase gneisses; less abundant are amphibole gneisses, amphibolites, and quartz-feldspar gneisses. The rocks of the Alutaguse zone have metamorphosed under the conditions of the amphibolite facies. In some places (Sonda-Uljaste and Haljala) the rocks show evidence of granulite facies metamorphism. Migmatization is common and strong in places.

The Jõhvi zone is characterized by strong E-W trending magnetic anomalies and quite variable positive gravity anomalies. The complex consists of pyroxene gneisses, quartz-feldspar gneisses, biotite-plagioclase gneisses, amphibole gneisses, garnet-cordierite gneisses (Vaivara complex), and magnetite-rich quartzites and gneisses (Jõhvi magnetic anomaly). Migmatization is widespread, resulting in the formation of plagioclase and potassium-feldspar porphyroblasts and occasionally charnockitic leucosomes, also of small granitoid veins and bodies. Generally, these rocks have formed under the conditions of granulite facies metamorphism.

The eastern part of the West Estonian zone is characterized by NW-SE striking strong linear magnetic anomalies, while the anomalies in the western part of the zone are mostly NE-SW or sub-N-S striking. The West Estonian zone is also cut by several Proterozoic tectonic zones, the largest of those being the HiiumaaEspoo shear zone. The main rock types are amphibole gneisses, amphibolites, biotite- and biotite-plagioclase gneisses, and quartz-feldspar gneisses with minor pyroxene gneisses. The mineral assemblage of these rocks refers to hightemperature subfacies of the amphibolite facies, in some places to granulite facies metamorphism. The latter often contains migmatites or small bodies of enderbitic composition, otherwise plagioclase-potassium-feldspar leucosomes and granites prevail.

The Tapa zone is bordered by tectonic contacts from the Tallinn zone in the west and Alutaguse zone in the east, while the southern contact with the West Estonian zone is not so clearly defined. The zone is characterized by positive gravity and magnetic anomalies. The main rock types include amphibole gneisses and amphibolites, which are in places intercalated with less abundant pyroxene gneisses, biotite-plagioclase gneisses, and quartz-feldspar gneisses. Mineralogical assemblages indicate amphibolite and granulite facies metamorphism. Migmatization has resulted in potassium-feldspar- and plagioclase-rich leucosomes and granitic veins and bodies and charnockitic veins in granulitic areas. Generally these rocks are mineralogically similar to those of the West Estonian zone.

The South Estonian zone is characterized by a band of intensive gravimagnetic anomalies embracing the southern part of Estonia and northern Latvia. The magnetic field is strongly differentiated, the anomalies are generally linear and 
trend $\mathrm{E}-\mathrm{W}$ or $\mathrm{N}-\mathrm{S}$. It is important to note that the gravity field anomalies are coarsely mosaic and often do not correlate with the magnetic anomalies. The boundary between the South and West Estonian zones generally follows the tectonic shear zones. The rock types show granulite facies metamorphic assemblages and comprise both mafic and felsic components - amphibole-pyroxene and biotitehypersthene gneisses, and quartz-feldspar gneisses. Minor amphibole gneisses, biotite-plagioclase (garnet, cordierite) gneisses and amphibolites are also found. Both charnockitic and granitic migmatization is observed.

\section{GEOPHYSICAL PATTERNS OF THE CRYSTALLINE BASEMENT ROCKS}

The structure of gravity and magnetic fields of Estonian territory has been studied since the early 1960s. Ideas about the sources for different types of geophysical anomalies have changed several times according to the results of deep drillings. The structural zonation of the basement on the basis of magnetic and gravity field patterns was first given by Fotiadi (1958). Later studies have changed the views about the age and origin of different anomaly sources but the general zonation has remained almost the same (Fig. 1).

The Precambrian basement consists of two megaunits separated by shear and thrust zones: the North Estonian Geophysical Low (low gravity and low magnetic) and the Baltic-Belarus Geophysical High (high gravity and variable, but mostly high magnetic). The regional gravity and magnetic highs in southern Estonia correspond to the granulite facies terrain, while the gravity and magnetic lows of northern Estonia correspond to the mainly amphibolite facies terrain.

The most pronounced shears and thrusts border the NW-SE-striking PaldiskiPskov zone. The west-east-striking nearly vertical Saaremaa tectonic zone (Middle Estonian share zone/fault is also used in literature) in its western portion separates parts of slightly different metamorphic grade: the proper granulite terrain in the south and the high-grade amphibolite facies rocks which are associated in places with granulitic areas. The vertical offset of blocks along this zone may reach up to some kilometres. As the Saaremaa zone crosscuts the post-orogenic plutonic rocks, it can be considered as formed during postorogenic and anorogenic faulting phases. The deep structure of these zones is in more detail described in All et al. (2004). Depending on the correlation of the level and pattern of gravity and magnetic fields with metamorphic grade and petrophysical properties of the upper part of the Earth's crust, the orogenic basement can be divided into six structural zones (listed above). The boundaries of these zones are in many cases marked by linear anomaly belts produced by different tectonic features like fault and fracture zones controlling later granite emplacement and granitization in situ.

Three-dimensional gravity and magnetic modelling results show that the faults of the Paldiski-Pskov zone dip southwestward $\left(65-75^{\circ}\right)$ and represent reverse 
faults. It has been proposed that they formed during the late compressional stage of the Svecofennian orogen in front of the regionally uplifted granulitic belts and blocks (All et al. 2004). Along the western margin of the Tapa block a NE-striking shear zone divides the northern Estonian basement into two parts.

Small- and middle-sized rapakivi granite massifs are often located within synorogenic faults within the basement. A series of NE-SW-striking shear and cataclastic fault zones are located in a belt between the largest Wiborg and Riga plutons. These zones also control the location of minor bodies of rapakivi in southern Finland and an ophitic gabbro body (Sigula) in the Tallinn zone. A number of minor massifs in mainland Estonia are located within or near the Paldiski-Pskov (Märjamaa, Naissaare) or other fault-related belts.

Besides the terrestrial phenomena there are some extraterrestrial ones causing quite prominent anomalies. The gravity and magnetic lows associated with the impact craters cavities result mainly from lower density and magnetization of crater filling. The gravity and magnetic maximums around the crater cavity can be interpreted as the effects of the elevated surface of the basement (Plado et al. 1996; Suuroja et al. 2002).

\section{AGE RELATIONSHIPS}

The first attempts to determine the isotopic age of Estonian basement rocks were made in the 1970s (Puura 1974). Three groups of isotope systematics (K$\mathrm{Ar}, \mathrm{Sr}-\mathrm{Rb}$, and U-Pb) were used in geochronological studies. In the early 1990s, $\mathrm{Sm}-\mathrm{Nd}$ analyses of the granulitic gneisses from the South Estonian drill cores were carried out (Huhma et al. 1991; Puura \& Huhma 1993). These results along with new U-Pb zircon age determinations (Petersell 1991, 1993; Petersell \& Levchenkov 1994; Rämö et al. 1996; A. Soesoo, unpublished data) eventually refuted the decades-long opinion about the Achaean age of the South Estonian granulites and suggested the Palaeoproterozoic age of 2.0-1.9 Ga for the granulite protolith.

The analysis of five fractions of metavolcanic rocks of the amphibolite facies of $\mathrm{N}$ and NE Estonia (drill core F-164) yielded a range of U-Pb zircon ages from 1.889 to $1.844 \mathrm{Ga}$, while the isochrone age is $1.918 \pm 10 \mathrm{Ga}$ (Petersell \& Levchenkov 1994; Fig. 2). Thirteen samples of the granulitic metavolcanic rocks which lie S and SW of the Paldiski-Pskov tectonic boundary (zone) yielded $\mathrm{U}-\mathrm{Pb}$ zircon ages between 1.833 and $1.802 \mathrm{Ga}$ and gave isochrone ages of $1.832 \pm 22$ and $1.827 \pm 7 \mathrm{Ga}$ (Petersell \& Levchenkov 1994). These ages are close to those of the post-orogenic(?) Taadikvere intrusion which cuts the metavolcanic rocks. The Taadikvere intrusion has the age of $1.833 \mathrm{Ga}$, thus being similar to Bäckaby granitoids of southern Sweden aged 1.834 \pm 4 Ga (Mansfeld 1996). Metavolcanites from the four drill cores of SW Estonia demonstrated an Sm-Nd model age $\left(\mathrm{T}_{\mathrm{DM}}\right)$ of $2.08-2.18 \mathrm{Ga}$, while $\varepsilon_{\mathrm{Nd}} \mathrm{T}$ varied from +0.2 to +2.0 (Huhma et al. 1991). 


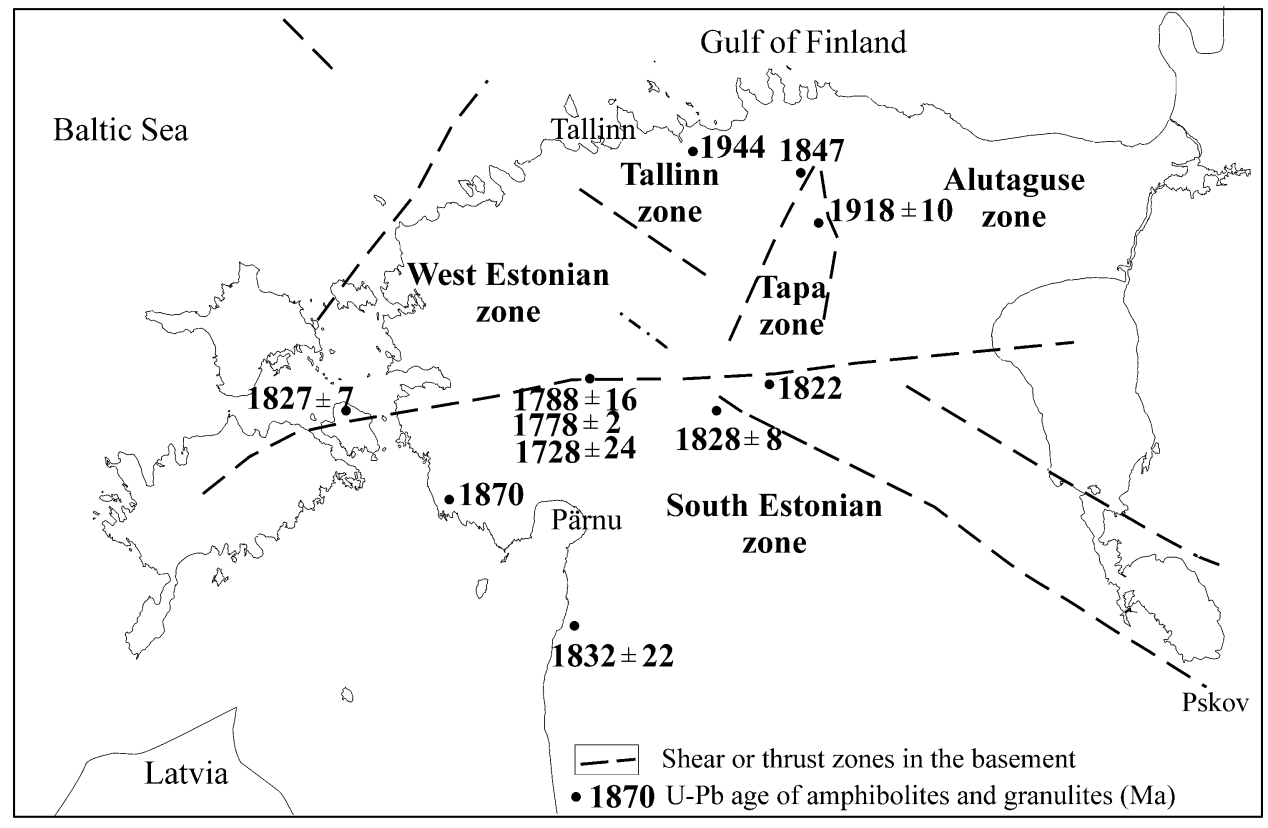

Fig. 2. U-Pb isotopic age and the main petrological-structural zones of the Estonian Proterozoic basement.

Al-rich gneisses from both North Estonian amphibolite (drill cores F-110 and F-113) and South Estonian granulite facies complexes (drill core 502) show the ranges of $\mathrm{U}-\mathrm{Pb}$ zircon ages from 2.128 to $1.847 \mathrm{Ga}$ and from 1.930 to $1.841 \mathrm{Ga}$, respectively (Fig. 2; Petersell \& Levchenkov 1994). They also show similar $\mathrm{T}_{\mathrm{DM}}$ and $\varepsilon_{\mathrm{Nd}} \mathrm{T}$ values of -2.30 to $2.30 \mathrm{Ga}$ and -1.9 to -1.6 , respectively (V. Petersell, unpublished data). These values are similar to the data obtained from Svecofennian metasediments (e.g. Huhma 1987), which have a mixed Palaeoproterozoic and Archaean provenance. Preliminary studies of zircons in Bt-gneisses (drill core F-502) by the laser ablation technique also shows a range of ages from 1.736 to possibly $1.900 \mathrm{Ga}$ (A. Soesoo, unpublished data). The relatively wide range of ages probably suggests mixed populations of zircons where some older, but radiogenically similar sedimentary material may be present.

The age of granulite metamorphism is difficult to estimate directly, however monazite from Estonian orthopyroxene-garnet gneiss (drill core F-300) yielded the age of $1.778 \pm 2 \mathrm{Ga}$ (H. Huhma, pers. comm. 2003). This age is similar to that of gabbro-noritic dyke which cuts the same granulites $-1.774 \pm 20 \mathrm{Ga}$ (A. Soesoo, unpublished data). The Sm-Nd age of garnets from this gneiss yielded the age of $1.728 \pm 24 \mathrm{Ga}$ which can be interpreted as the age when the rocks cooled down to the closure temperature of garnets, i.e. ca. $650-700^{\circ} \mathrm{C}$. The associated charnockitic rocks gave comparable ages of $1.788 \pm 16 \mathrm{Ga}$ (A. Soesoo, unpublished data). 
These ages of the southern Estonian granulites are clearly younger than any comparable results from Finland, and suggest that the granulite facies metamorphism in this area is definitely distinct from that recorded in the Fennoscandian Shield.

Very few proper age data are available from post-orogenic magmatic rocks of the Estonian basement. K-Ar dating of biotite and amphibole from the granitic bodies cutting Svecofennian metamorphic complexes in NE Estonia yielded the ages of 1.648-1.345 Ga (Puura et al. 1983 and references therein). The granitic rocks emplaced into the Abja mafic intrusion show zircon fractions with ages from 1.610 to $1.515 \mathrm{Ga}$ with the isochrone age of $1.622 \pm 7 \mathrm{Ga}$ (Kirs \& Petersell 1994). The gabbronoritic dyke mentioned above, which cuts granulitic gneisses (drill core F-300) yielded the preliminary U-Pb age of $1.774 \pm 20 \mathrm{Ga}$ (A. Soesoo, unpublished data).

The age of the Estonian anorogenic granites is, however, well dated. An overview is presented below, in the section "Post- and anorogenic magmatic rocks in the Estonian basement".

Relying upon the available data, it can be concluded that the Svecofennian orogenic structures in the Estonian basement formed during Palaeoproterozoic time, 1.9-1.8 Ga ago and are composed of magmatic, volcanic, and sedimentary components across both major structural zones. The granulite metamorphism and possibly associated mafic magmatism (including crustal melting events) postdate these ages. The older material may be possibly transported from a continental fragment existing in the NW. It is not clear yet whether the age differences between granulite (SW Estonia) and amphibolite facies volcanic rocks (NE Estonia) hint at differences in the geotectonic position of these rocks. Neither is it clear how the granulites are structurally related to the adjacent rocks.

\section{METAMORPHISM}

Svecofennian (Palaeoproterozoic) orogenic, folded metamorphic rocks dominate in the basement structure of Estonia. The amphibolite facies terrain of the Tallinn zone of northern Estonia consists of a sequence of metavolcanics and -sediments, which resemble those of the island arc sequences in southern Finland. The Alutaguse zone of northern Estonia comprises mostly metapelites similar to those of NE marginal metasedimentary basins of the Svecofennian orogen, studied in the St. Petersburg District (NW Russia) and SE Finland (Puura et al. 1983; Koistinen 1994, 1996). In western Estonia, the primary lithology of the dominating mafic amphibolite facies metavolcanics resembles that of the South Estonian granulites. A number of metamorphic domes have been determined, showing granulite facies assemblages, such as Haapsalu in western Estonia; Tapa, Uljaste, and Jõhvi in NE Estonia, and Slantsy in NW Russia (see Puura et al. 2004). 
Southern Estonia comprises metamorphosed intermediate and mafic metavolcanics of the granulite facies, with a few metasediment localities. The South Estonian Granulite Domain is probably a part of the Belarus-Baltic high-grade metamorphic region, which extends in WNW-ESE direction from southern Estonia to Latvia and has NNE-SSW orientation in Lithuania, Poland, and Belarus. Linear magnetic and gravity anomalies with $\mathrm{E}-\mathrm{W}$ orientation are characteristic of the South Estonian Granulite Domain. It is also important to mention that the granulite terrain of southern Estonia and northern Latvia is much larger than any known granulite area in the Svecofennian Domain.

The peak metamorphism conditions of granulites in southern Estonia are about $800^{\circ} \mathrm{C}$ and 5-6 kbar, which are similar to those of granulites of the Central Finnish Pielavesi area (Hölttä \& Klein 1991). The relatively high pressure compared to the North Estonian amphibolite facies areas indicates a much deeper erosional level (>20 km) for the South Estonian zone.

As noted above, many questions about the spatiotemporal relationships between the granulite and amphibolite facies domains and their positions within the Fennoscandian framework remain still unanswered. A more detailed overview of the metamorphism of Estonian basement rocks is presented in Puura et al. (2004).

\section{PRECAMBRIAN IGNEOUS ROCKS IN THE ESTONIAN BASEMENT}

Svecofennian igneous rocks are widely distributed in the crystalline basement of Estonia. Granitic rocks usually dominate and are present in about 400 of the total of 500 drill cores. The group of acid igneous rocks also contains effusive varieties, which are found in more than 80 drill cores. Intermediate to basic and ultrabasic rocks are less spread - they are described in about 80 drill cores.

Based on drill core observations, Estonian Svecofennian granitoids are traditionally divided into syn- and late-orogenic granites (Niin 1997). In the Estonian basement, the synorogenic granitoids are recorded in about 50 drill cores, whereas hypersthene-bearing charnockites and enderbites predominate. Geochemically, synorogenic granites show I-type characteristics and their genesis is related to granulitic metamorphism (Niin 1997), although some authors have treated them together with late-orogenic migmatite granites (Puura et al. 1997). These granites are widespread in the South Estonian and Jõhvi granulitic zones, where they form veins, "shadow-granites", and small lenses and bodies. The other group of synorogenic granitoids is represented by granodiorites and occasionally by quartz diorites. These rocks show gneissic structure and occur mainly as small plutons. They are usually found in the Tallinn and Jõhvi zones.

The Estonian late-orogenic granitoids occur in more than 300 drill cores and are known in all structural zones, however, less often in the South Estonian and Jõhvi granulitic zones. In the mineral and chemical composition granites, granodiorites, and syenogranites dominate; tonalites and adamellites occur less often, 
while quartz diorites, quartz monzonites, and quartz syenites are recorded only in a few drill cores. Usually they form veins, but migmatitic rock bodies are also frequent. The granites are mainly massive, pegmatoid texture is common, gneissic varieties are rare, while porphyraceous texture occurs very seldom. Most of them are probably of metasomatic or anatectic origin (S-type granites; Niin 1997).

Most of the quartz-feldspar- and granite-gneisses, such as dacites, rhyolites, porphyries, etc., are considered to belong to acid metavolcanites (Niin 1997). The silicate ferruginous quartzites (taconites) in the Jõhvi zone are also likely of volcanic origin. The acid metavolcanic rocks are most common in the West Estonian and Tallinn zones.

Intermediate rocks of probably igneous origin in the crystalline basement of Estonia are recorded in about 40 drill cores, half of which are situated in the West Estonian zone. The main types of intermediate igneous rocks are gabbrodiorites (metagabbrodiorites), diorites (metadiorites), and different gneisses.

Basic igneous rocks in the Estonian crystalline basement are recorded in more than 70 drill cores. Half of the cores are located in the West Estonian zone (Niin 2002). Among the rocks metagabbroids play an important role and occur in all structural zones. Like the other basement rocks in Estonia, they are often considerably metamorphosed, but contain frequently relicts of the primary characteristic textures. Gabbroids are mainly amphibolized, but in places have also been subjected to gneissic layering, granitization, and migmatization. As a result of these processes, metaigneous mafic rocks may transfer into typical metamorphic rocks - amphibolites and gneisses. Besides intrusive rocks, some veins as well as effusive basic rocks are represented.

The share of ultrabasic igneous rocks in the crystalline basement of Estonia is small and commonly they have been largely altered during metamorphism and secondary processes (Niin 2002). Ultrabasic rocks - metaperidotites, serpentinites, and melanocratic amphibolites - are described only in four drill cores, where they form veins of different thickness inside the basic rocks.

The more precise tectonic position of basic igneous rocks, either syn- or lateorogenic, is complicated to identify. However, it is quite probable that most of them belong rather to the synorogenic rock group.

\section{POST- AND ANOROGENIC MAGMATIC ROCKS IN THE ESTONIAN BASEMENT}

Within the Estonian basement post-orogenic (later than Svecofennian collisional processes) and anorogenic (independent of Svecofennian orogenic framework) magmatic rocks were recognized by drilling and from gravity and magnetic investigations back in the middle of the 20th century (Tikhomirov 1965; Bogatikov \& Birkis 1973; Kuuspalu 1975; Puura et al. 1976, 1983; Velikoslavinsky et al. 1978; Kirs \& Petersell 1994; Rämö et al. 1996). This rock group is relatively well studied. 
The anorogenic rocks belong to the Fennoscandian Palaeo-Mesoproterozoic Rapakivi Province (Koistinen 1994; Rämö \& Haapala 1995; Puura \& Floden 1999) and include the huge composite Riga batholith, as well as at least five minor stock-like porphyritic K-granite plutons - Naissaare, Märjamaa (with its Kloostri satellite), Neeme, Ereda, and a quartz-monzodioritic Abja stock in SW Estonia (Kuuspalu 1975; Soesoo \& Niin 1992; Soesoo 1993; Kirs et al. 2004). All the rock bodies, except the Abja pluton, are situated in northern Estonia (Fig. 1; see also Kirs et al. 2004).

The anorogenic Riga pluton that forms the southern part of the Riga-Åland rapakivi subprovince (Puura \& Floden 1999) contains both mafic and silicic rocks, which are petrographically and geochemically analogous to the typical members of the Fennoscandian rapakivi-anorthositic suite. As in the case of other large rapakivi granite batholiths, considerable effect of crustal thinning - in scale of $10 \mathrm{~km}$ - has occurred in the area of the Riga batholith (Puura \& Floden 1999, 2000). Zircons from the leucogabbronorite and biotite-hornblende granite of the Riga pluton have $\mathrm{U}-\mathrm{Pb}$ ages of $1.576 \pm 2 \mathrm{Ga}$ and $1.584 \pm 7 \mathrm{Ga}$, respectively (Rämö et al. 1996).

The stocks of the porphyritic K-granites in the Estonian mainland show up as small gravity and magnetic minima (Ereda, Neeme, Naissaare, Taebla, and Kloostri stocks) and comprise pink, medium- to coarse-grained, microclinemegacrystic, partly trachytoid biotite (in Märjamaa and Naissaare also biotitehornblende) syeno- and monzogranitic rock, locally cut by aplitic and microsyenitic dykes (Kuuspalu 1975; Kirs 1986; Soesoo \& Niin 1992). As an exception, the Märjamaa pluton is more differentiated with the anomalously high magnetic central part containing hybrid granodiorite with hastingsitic hornblende as the main mafic mineral. The major and trace element contents of the Estonian porphyritic potassium granites are close to or overlapping those of typical Finnish rapakivi and comparable with the less differentiated granitic phases from the Wiborg and Laitila plutons (Kuuspalu 1975; Kirs et al. 1991; Soesoo \& Niin 1992). Specifically, the Märjamaa granodiorite is more enriched with $\mathrm{Sr}, \mathrm{Ti}$, and P (Petersell \& Kirs 1992). The REE contents of the Estonian porphyritic potassium granites vary also within the limits characteristic of the southern Finland rapakivi granites (see Kirs et al. 2004). Zircons from the Märjamaa granodiorite show the $\mathrm{U}-\mathrm{Pb}$ age of $1.629 \pm 7 \mathrm{Ga}$, and from the Naissaare biotite-hornblende granite, $1.624 \pm 10 \mathrm{Ga}$ (Rämö et al. 1996).

The Abja quartz-monzodioritic stock in SW Estonia is strongly magnetic and consists of a dark grey, massive, medium-grained, partly weakly gneissose rock with abundant accessory apatite and titanomagnetite. It is intersected by veins of fine- to medium-grained, slightly porphyritic plagioclase-microcline granite. The $\mathrm{U}-\mathrm{Pb}$ zircon age is $1.635 \pm 7 \mathrm{Ga}$ for monzodiorite and $1.622 \pm 6 \mathrm{Ga}$ for granite (Kirs \& Petersell 1994).

The unmetamorphosed NE-SW oriented Sigula intrusion in North Estonia consists of medium-grained gabbro-monzonitic rock with ophitic texture and of 
massive structure. This rock is very rich in titanomagnetite (up to 10\%), apatite (2-4\%), and titanite. The other post-orogenic body, the Utria stock in NE Estonia consists of medium-grained fresh, not amphibolized gabbrodiorite with a high (3-5\%) titanite content.

Whole-rock isotopic data from the Riga, Märjamaa, Naissaare, Neeme, and Abja plutons indicate an approximately chondritic source for $\mathrm{Nd}$ in the mafic rocks of the Riga batholith and the Abja intrusion, and a Palaeoproterozoic (Svecofennian) protolith for the felsic rocks - the $\mathrm{T}_{\mathrm{DM}}$ model ages of the felsic rocks range from 2.10 to $1.89 \mathrm{Ga}$ (Rämö et al. 1996). The $\mathrm{Nd}$ and $\mathrm{Pb}$ isotopic compositions of the felsic and mafic rocks from the Riga, Märjamaa, Naissaare, Neeme, and Abja plutons are very similar to those of the Finnish rapakivi complexes (Rämö 1991) and show that the lower crust and the subcontinental mantle are devoid of a (major) Archaean component (Rämö et al. 1996).

\section{METALLOGENY}

During the 1950s-1980s, the Estonian basement rocks were extensively drilled and studied for ore and metals. From the metallogenetic point of view, the geochemically anomalous Jõhvi-Uljaste sidero-chalcophilic area is the most promising. The area was identified a century ago on the ground of strong magnetic anomalies. These anomalies are caused by magnetite quartzites (Jõhvi and Sakusaare anomalies) and sulphide-graphite-bearing gneisses (Uljaste, Haljala, and Assamalla anomalies) within the crystalline basement. The Jõhvi magnetite quartzites occur as subvertical beds in garnet-cordierite or pyroxene gneisses. Drill core study shows that the complex of gneisses and magnetite quartzites is about $100 \mathrm{~m}$ thick, and the reserves of iron ore (Fe over $25 \%$ ) are about 355 million tonnes (calculated to a depth of $500 \mathrm{~m}$ ) and 629 million tonnes (calculated to a depth of $700 \mathrm{~m}$ ). The Sakusaare iron ore locality is much smaller and the iron content is usually lower. The sulphidic ore consists of pyrrhotite and lesser amounts of pyrite, sphalerite, galenite, and chalcopyrite. Occasional sulphide and polymetallic ore-bearing sites and other geochemical anomalies are related to metamorphosed black schists of the Jägala complex (Tallinn zone). Some gabbroic rocks, e.g. from the Sigula and Vanaküla intrusions, are rich in apatite, ilmenite, and magnetite. Higher $\mathrm{Ni}$ and $\mathrm{Cr}$ contents are associated with komatitic(?) amphibolites (NW ESTONIA).

\section{ACKNOWLEDGEMENTS}

We thank two anonymous reviewers for useful suggestions. A. S. acknowledges financial support from the Estonian Science Foundation (grants Nos. 4615 and 5301). 


\section{REFERENCES}

All, T., Puura, V. \& Vaher, R. 2004. Orogenic structures of the Precambrian basement of Estonia as revealed from the integrated modelling of the crust. Proc. Estonian Acad. Sci. Geol., 53, $165-189$.

Baker, J. A., Hellingwerf, R. H. \& Oen, I. S. 1988. Structure, stratigraphy and ore-forming processes in Bergslagen: implications for the development of the Svecofennian of the Baltic Shield. Geol. Mijnbouw, 67, 121-138.

Bogatikov, O. A. \& Birkis, A. P. 1973. Precambrian Magmatism of Western Latvia. Nauka, Moscow (in Russian).

Bondarenko, L. \& Dagelaiskii, V. 1968. Geology and Metamorphism of the Central Part of Kola Peninsula. Nauka, Leningrad (in Russian).

Fotiadi, E. E. 1958. Geologicheskoe stroenie russkoj platformy po dannym regional'nykh geofizicheskikh issledovanij i opornogo bureniya. Gosgeoltechizdat, Moscow (in Russian).

Gaal, G. 1990. Tectonic styles of Early Proterozoic ore deposition in the Fennoscandian Shield. Precambrian Res., 46, 83-114.

Gorbatschev, R. \& Gaal, G. 1987. The Precambrian history of the Baltic Shield. In Proterozoic Lithospheric Evolution (Kroner, A., ed.), pp. 149-159. American Geophysical Union, Washington.

Grigelis, A. \& Puura, V. (eds.). 1978. Geological map of the crystalline basement of the Soviet Baltic Republics. Scale 1:500 000.

Hietanen, A. 1975. Generation of potassium-poor magmas in the northern Sierra Nevada and the Svecofennian in Finland. J. Res. U.S. Geol. Surv., 3, 631-645.

Hölttä, P. \& Klein, V. 1991. PT-development of granulite facies rocks in southern Estonia. Geol. Surv. Finland Spec. Pap., 12, 37-47.

Huhma, H. 1987. Provenance of early Proterozoic and Archaean metasediments in Finland: a Sm-Nd isotopic study. Precambrian Res., 35, 127-143.

Huhma, H., Puura, V., Klein, V. \& Mänttäri, I. 1991. Nd-isotopic evidence for Paleoproterozoic crust in Estonia. Geol. Surv. Finland Spec. Pap., 12, 67-68.

Kirs, J. 1986. X-ray and optical investigation of feldspars from Estonian early platform potassium granites. Acta Comment. Univ. Tartuensis, 759, 3-19 (in Russian).

Kirs, J. \& Petersell, V. 1994. Age and geochemical character of plagiomicrocline granite veins in the Abja gabbro-dioritic massif. Acta Comment. Univ. Tartuensis, 972, 3-15.

Kirs, J., Huhma, H. \& Haapala, I. 1991. Petrological-chemical features and age of Estonian anorogenic potassium granites. In Symposium on Rapakivi Granites and Related Rocks, Abstract Volume (Haapala, I. \& Rämö, O. T., eds.), Geol. Surv. Finland, 34, 28-29.

Kirs, J., Haapala, I. \& Rämö, O. T. 2004. Anorogenic magmatic rocks in the Estonian crystalline basement. Proc. Estonian Acad. Sci. Geol., 53, 210-225.

Koistinen, T. (ed.). 1994. Precambrian basement of the Gulf of Finland and surrounding area. Map $1: 1000$ 000. Geological Survey of Finland, Espoo.

Koistinen, T. (ed.). 1996. Explanation to the Map of Precambrian basement of the Gulf of Finland and surrounding area 1:1000 000. Geol. Surv. Finland Spec. Pap., 21, Espoo.

Koppelmaa, H. 2002. (ed.). Geological map of the crystalline basement of Estonia. Scale $1: 400$ 000. Geological Survey of Estonia, Tallinn.

Kuuspalu, T. 1975. Rapakivi granites of the crystalline basement of Estonia. Acta Comment. Univ. Tartuensis, 359, 76-141 (in Russian).

Lahtinen, R. 1994. Crustal evolution of the Svecofennian and Karelian domains during 2.1-1.79 Ga, with special emphasis on the geochemistry and origin of 1.93-1.91 Ga gneissic tonalites and associated supracrustal rocks in the Rautalampi area, central Finland. Geol. Surv. Finland Bull., 378. 
Mansfeld, J. 1996. Geological, geochemical and geochronological evidence for a new Palaeoproterozoic terrane in south-eastern Sweden. Precambrian Res., 77, 91-103.

Niin, M. 1997. Svecofennian granitoids of the crystalline basement of Estonia: classification on the basis of geological structure, mineral and chemical composition. Eesti Geoloogiakeskuse Toim., 7, 4-40.

Niin, M. 2002. Non-acid igneous rocks of the crystalline basement of Estonia. Eesti Geoloogiakeskuse Toim., 10, 4-19.

Nironen, M. 1997. The Svecofennian Orogen: a tectonic model. Precambrian Res., 86, 21-44.

Öpik, A. 1942. Über Magnetometrie und die Geologie des Urgebirges von Estland. (Manuscript at the Institute of Geology, University of Tartu).

Park, A. F. 1991. Continental growth by accretion: a tectonostratigraphic analysis of the evolution of the western and central Baltic Shield, 2.5 to 1.75 Ga. Geol. Soc. Amer. Bull., 103, 522537.

Petersell, V. 1991. On the geological age of the crystalline basement of the southern slope of the Baltic Shield (SSBS). Eesti Geoloogiakeskuse Toim., 1, 25-26.

Petersell, V. 1993. The age of plagiomicrocline granites in the crystalline basement of Estonia. In Symposium on the Svecofennian Domain and Annual Meeting of IGCP-275. Department of Geology, Åbo Akademi, Turku, 46.

Petersell, V. \& Kirs, J. 1992. Geochemical character of Estonian subplatform granitoids and gabbroids. Acta Comment. Univ. Tartuensis, 956, 27-43.

Petersell, V. \& Levchenkov, O. 1994. On the geological structure of the crystalline basement of the southern slope of the Baltic Shield. Acta Comment. Univ. Tartuensis, 972, 3-15.

Plado, J., Pesonen, L., Elo, S., Puura, V. \& Suuroja, K. 1996. Geophysical research on the Kärdla impact structure, Hiiumaa Island, Estonia. Meteorit. Planet. Sci., 31, 289-298.

Puura, V. 1974. K-Ar isotopic age of the rocks of the crystalline basement of the East Baltic. Eesti NSV Tead. Akad. Toim. Keemia Geol., 23, 40-50.

Puura, V. (ed.). 1980. Geological map of the crystalline basement of the East Baltic. Scale $1: 1000$ 00. VSEGEI, Leningrad.

Puura, V. \& Floden, T. 1999. Rapakivi-granite - anorthosite magmatism - a way of thinning and stabilisation of the Svecofennian crust, Baltic Sea Basin. Tectonophysics, 305, 75-92.

Puura, V. \& Floden, T. 2000. Rapakivi-related basement structures in the Baltic Sea area, a regional approach. GFF, 122, 257-272.

Puura, V. \& Huhma, H. 1993. Palaeoproterozoic age of the East Baltic granulite crust. Precambrian Res., 64, 289-294.

Puura, V., Kuuspalu, T., Birkis, A., Vasiljev, B. A., Gaulius, R., Koppelmaa, H. \& Niin, M. 1976. Outlines of the geological structure of Precambrian basement of Baltic States. In Geologiya, petrologiya i metallogeniya kristallicheskikh obrazovanij Vostochno-Evropejskoj platformy. Part I, pp. 40-48. Nedra, Moscow (in Russian).

Puura, V., Vaher, R., Klein, V., Koppelmaa, H., Niin, M., Vanamb, V. \& Kirs, J. 1983. The Crystalline Basement of Estonian Territory. Nauka, Moscow (in Russian).

Puura, V., Klein, V., Koppelmaa, H. \& Niin, M. 1997. Precambrian basement. In Geology and Mineral Resources of Estonia (Raukas, A. \& Teedumäe, A., eds.), pp. 27-34. Estonian Academy Publishers, Tallinn.

Puura, V., Hints, R., Huhma, H., Klein, V., Konsa, M., Kuldkepp, R., Mänttäri, I. \& Soesoo, A. 2004. Svecofennian metamorphic zones in the basement of Estonia. Proc. Estonian Acad. Sci. Geol., 53, 190-209.

Rämö, O. T. 1991. Petrogenesis of the Proterozoic rapakivi granites and related basic rocks of southeastern Fennoscandia: $\mathrm{Nd}$ and $\mathrm{Pb}$ isotopic and general geochemical constraints. Geol. Surv. Finland Bull., 355, 161.

Rämö, O. T. \& Haapala, I. 1995. One hundred years of Rapakivi Granite. Mineral. Petrol., 52, $129-185$. 
Rämö, T., Huhma, H. \& Kirs, J. 1996. Radiogenic isotopes of the Estonian and Latvian rapakivi granite suites: new data from the concealed Precambrian of the East European Craton. Precambrian Res., 79, 209-226.

Soesoo, A. 1993. Estonian porphyraceous potassium granites: petrochemical subdivision and petrogenetical interpretation. Proc. Estonian Acad. Sci. Geol., 42, 97-109.

Soesoo, A. \& Niin, M. 1992. Petrographical and geochemical features of the Estonian porphyritic potassium granites. Proc. Estonian Acad. Sci. Geol., 41, 93-107.

Suuroja, S., All, T., Plado, J. \& Suuroja, K. 2002. Geology and magnetic signatures of Neugrund Impact Structure, Estonia. In Impacts in Precambrian Shields (Plado, J. \& Pesonen, L., eds.), pp. 277-295. Springer Verlag.

Tikhomirov, S. N. 1965. New rapakivi granite massifs in Baltic and Leningrad districts. Dokl. Akad. Nauk SSSR, 164, 889-890.

Velikoslavinsky, D. A., Birkis, A. P., Bogatikov, O. A., Bukharev, V. P., Velikoslavinsky, S. D., Gordiyenko, L. I., Zinchenko, O. V., Kivisilla, J. J., Kirs, J. E., Kononov, Ju. V., Levitsky, Ju. F., Niin, M. I., Puura, V. A., Khvorov, M. I. \& Shustova, L. Je. 1978. AnorthositeRapakivigranite Formation of the East European Platform. Nauka, Leningrad (in Russian).

\title{
Eesti eelkambriumi vanusega aluskorra põhijooni
}

\author{
Alvar Soesoo, Väino Puura, Juho Kirs, Valter Petersell, \\ Mati Niin ja Tarmo All
}

Eesti eelkambriumi vanusega aluskord jaguneb mitmeks suuremaks petroloogilis-struktuurseks vööndiks: Tallinna, Alutaguse, Tapa, Lääne-Eesti ja LõunaEesti vöönd. Paldiski-Pihkva tektooniline vöönd jagab aluskorra amfiboliitse faatsiese kivimitega esindatud põhja- ja granuliitse faatsiese kivimitega esindatud lõunaosaks. Artiklis kirjeldatakse nimetatud vööndite kivimilist koostist ja metamorfismi ning vöönditega seonduvaid geofüüsikalisi välju. Tuuakse ära olemasolevad aluskorrakivimite vanuselised andmed ning kirjeldatakse porfüürilaadseid K-rikkaid graniite. 